\title{
Learning Media Based on Google Form as an Alternative to Improve Students Critical Thinking Ability
}

\author{
Riana Wirya Arwati ${ }^{1}$, Ine Kusuma Aryani ${ }^{2}$ \\ $\left\{\underline{\text { rianawirya@gmail.com }}{ }^{1}, \underline{\text { inepascapendas@gmail.com }}{ }^{2}\right.$ \} \\ ${ }^{1}$ SD Negeri 1 Krandegan, Jl Dipayuda No.23, Banjarnegara 53414 \\ ${ }^{2}$ Magister Pendidikan Dasar, Universitas Muhammadiyah Purwokerto, Jl KH Ahmad \\ Dahlan, Banyumas 53182, Indonesia
}

\begin{abstract}
This study aims to see the use of Google Form-based learning media as an alternative to improve students critical thinking skills. Learning media is a means to convey learning material. Learning media can be in the form of textbooks, student worksheets, modules, digital applications, learning videos, etc. The type of data used is secondary data. The method used in this research is the literature study method. The data obtained were collected, analyzed, and concluded to get conclusions about the literature study. Based on the research results, literature studies from several research results and journal articles show that the use of Google Form-based learning media can improve students critical thinking skills.
\end{abstract}

Keywords: learning media, students' ability, critical thinking skills

\section{Introduction}

Students can easily access learning media that have adopted the latest technology. Applications and learning videos in the 4.0 era have become more attractive accesses to develop student interest in learning. With the development of instructional media, students can learn independently by understanding the material and practicing solving a problem, not wholly depending on the material presented by the teacher during classroom learning. Student worksheet is one of the media that can be developed. Student worksheet can be created using one of the platforms already owned by Google, namely the Google Form. Google form is straightforward to use to meet the demands of learning in the 4.0 era [1].

Google forms have very diverse uses ranging from doing surveys, collecting data, and taking quizzes or tests that present through an online website. Google forms are easy to modify and share with students by sending the link to students. Other than that, Google form also has the advantage of the flexibility to add illustrations in the form of images and videos that can support the student learning process independently. The illustration, videos, and pictures can be accessed by students repeatedly, anytime, and wherever students are. Therefore, students who cannot understand the material quickly can repeat in learning the material given to understand [2]. 
The results of student work can also be recorded automatically and can be sent directly to the teacher. The results are in the form of an online file that is arrange according to the students access history. Therefore, teachers can quickly evaluate and monitor student's understanding obtained from working on the given worksheets. Students who cannot understand the material soon can repeat in studying the material presented to understand. The results of student work can also be recorded automatically and can be sent directly to the teacher. The results are in the form of an online file that has been compiled according to the student's access history. Therefore, teachers can quickly evaluate and monitor students' understanding obtained from working on the given worksheets. Students who cannot understand the material quickly can repeat in studying the material presented to understand. The results of student work can also be recorded automatically and can be sent directly to the teacher. The results are in the form of an online file that is arrange according to the student's access history. Therefore, teachers can soon assess and monitor students' understanding obtained from working on the provided worksheets. Teachers can quickly evaluate and monitor student understanding obtained from the work of the given worksheets. [1].

The PISA results show that the achievement of Indonesian students is still at the lowest rank. Indonesian is ranked 64th out of 65 countries participating in PISA 2018. (OECD, 2018). According to Rohman (2011), the still low student learning outcomes so far are not only caused by a lack of mastery and understanding of the subject matter that has been taught but can also be due to evaluation factors or questions such as providing practice questions and homework assignments or available homework. In the student handbook, even though the student handbook used only provides questions that do not trigger students to think critically [2].

In the 2013 curriculum, it is clear that the skills that students must have in the 21 st century are 4C (Communication, Collaboration, Critical Thinking, and Problem Solving, Creative, and Innovation), so every student must be able to communicate well, work with teams, think critically, can solve a problem, be creative, and contantly innovate. In carrying out critical thinking, engaging in a thinking position characterized by: asking clearly and reasonedly, trying to understand well, using reliable sources, considering the situation as a whole, trying to keep referring and relevant to the main problem, looking for various alternatives, being open, dare to take a position, act quickly, have an attitude or view that something is part of a complex whole, take advantage of the critical thinking of others and be sensitive to the feelings of others. [3].

The linkage of critical thinking in learning needs to prepare students to become reliable problem solvers, mature decision-makers, and people who never stop learning. So that all students are actively involved in critical thinking, the teacher must find other alternatives that can facilitate students to develop critical thinking. One of them using of student worksheets, where each student can express their ideas and opinions in criticizing problems. Student worksheets is very well used to activate student involvement in learning both, used in the application of learning and providing development exercises. [4].

The teacher's role is more of a facilitator and must improve the quality of learning. Therefore teachers are required to constantly innovate in carrying out the learning process. The teacher's innovation is, for example, in terms of choosing the right teaching material learning approach.

Where the arrangement of student worksheets is anticipated to be able to alter the learning conditions from teacher-centered to student-centered, which more often than not decides what teachers learn in a lesson. Student worksheets is one of the suitable learning choices for students 
since student worksheets makes a difference students to include data approximately the concepts learned through orderly learning exercises. The use of student worksheets is efficient and includes several practice questions. [5].

The teaching-learning process ends with an assessment. So that the teacher can consider different ways in his class. Manual reviews will take a lot of time to complete. It is also prone to human error. Before the digital era came, the evaluation given by teachers in the teaching and learning process carry out on paper. The questions typed on paper are then copied as a number as a student number. This condition is often a crucial problem for schools whose school management has to spend too much money on these activities. [6]. Google forms is an application provided by Google for free to meet user needs in the form of a template and has various functions and uses. Google forms can solve teacher difficulties. The multiple forms provided can be used for learning purposes, such as surveys, exam forms, activity sheets which can all be done online (without paper). Learning will also be more fun and interactive. By preparing worksheets via Google forms, it creates an interactive and time-efficient learning environment. [7].

Solving problems is an essential activity for humans or high mental activity. Most people are faced with problems, so it is necessary to find a solution (Hudojo, 2003). Students are required to be able to think critically not just think simple in solving problems. Critical thinking means thinking clearly and intelligently. [8].

Based on the background description and literature review, a suitable alternative to improve students' critical thinking skills is using google form-based learning media. Students' critical thinking skills are expected to increase with the use of this google form-based learning media.

\section{Research Methods}

This research is a literature review research. The data taken in this study is secondary data. Secondary data is data taken not from direct observers but from the results of research by previous researchers. The data collection method used in this research is the documentation method. The documentation method is a systematic data collection procedure for reviewing both printed and electronic documents [9]. The documentation method is a data collection method by finding or extracting data from literature related to what is meant in the problem formulation. The data analysis used in this research is bibliographic annotation analysis. Annotation indicates a simple conclusion from an article, book, journal, or some other written source.

\section{Discussion}

Learning media can briefly be stated as something (can be a tool, material, or situation) that is used as an intermediary for communication in learning activities. [10]. Student worksheets are student guides used to carry out investigative activities and problem-solving. Student Worksheets is used to help students in learning activities together information, find information, apply concepts and develop concepts that have been learned. In line with that, student worksheets can be used by students based on $4 \mathrm{C}$ abilities in thematic learning [11].

Critical thinking is analyzing information correctly, carefully, looking for valid evidence, and producing solid conclusions to believe and do something [8][12]. A person can obtain information correctly. Through the process of thinking critically, evaluating it and processing the information so that a reliable conclusion is received. [12]. The steps for making student 
worksheets are the stages of preparation, design, and implementation. Some of the student worksheets produced are narrative, audio-visual and link models. [13]. Critical thinking ability can explain problem-solving ability. [14].

Based on the results of the study, it shows that the development of student worksheets with a guided inquiry approach based on mobile learning from the results of the validator is excellent and feasible and can optimize critical thinking skills along with positive attitudes of students. [15]. The results of other research validation results show that the developed student worksheets are in the good category. Process skills improve so that it can be said that the worksheets created are feasible and practical. [16]. The results showed that using the Google Form application has many advantages for teachers, especially for assessing students' abilities in subjects. [17]. Interactive teaching materials trigger students to have critical thinking skills. According to Darmojo and Kaligis, teaching student worksheets in the teaching and learning process provides benefits, including making it easier for teachers to manage the teaching and learning process in changing the learning conditions that were initialy teacher-centered to being student-centered. Students will work seriously and with a sense of responsibility for the tasks given to them. They are mainly looking for the concepts they have learned. [18-19].

\section{Conclusions}

Based on the background of the problem and the results of the literature study presented, critical thinking skills can be improved using Google Form-based learning media. The author hopes this paper is an alternative study for teachers and other parties involved in improving critical thinking skills. The Google Form application is recommended by the author so that it can be used as a learning media. Teachers can make assignments and home study projects using them. The use of digital technology can streamline learning.

\section{References}

[1] Sadewa IW, Suharta IG, Astawa IW. Pengembangan Lembar Kerja Siswa (LKS) Berbantuan Google form pada Pokok Bahasan Bangun Ruang Untuk Mengoptimalkan Hasil Belajar. Jurnal

Mercumatika: Jurnal Penelitian Matematika dan Pendidikan Matematika. 2020 Oct 31;5(1):34-45. [2] Fitriana D, Yusuf M, Susanti E. Pengembangan Lembar Kerja Siswa Menggunakan Pendekatan Saintifik Untuk Melihat Berpikir Kritis Siswa Materi Perbandingan. Jurnal Pendidikan Matematika. 2016;10(2):1-7.

[3] Sadiyyah R, Gustiana M, Panuluh SD, Sugiarni R. Pengembangan Lembar Kerja Siswa (LKS) dengan pendekatan inkuiri terbimbing berbasis mobile learning untuk mengoptimalkan kemampuan berpikir kritis matematis. Prisma. 2019 Jun 30;8(1):80-95.

[4] Astuti P, Purwoko P, Indaryanti I. Pengembangan LKS untuk melatih kemampuan berpikir kritis dalam mata pelajaran matematika di kelas VII SMP. Jurnal Gantang. 2017 Oct 4;2(2):145-55.

[5] Astari T. Pengembangan lembar kerja siswa (LKS) berbasis pendekatan realistik untuk meningkatkan hasil belajar siswa SD kelas IV. Jurnal Pelangi. 2017 Sep 10;9(2):150-160

[6] Wahyuni I, Supandi T, Ekanara B. DEVELOPING DIGITAL WORKSHEET BASED ON ANDROID SUBJECT BIODIVERSITY GASTROPODS IN MANGROVE FOREST AT TUNDA ISLAND BANTEN. BIODIDAKTIKA: JURNAL BIOLOGI DAN

PEMBELAJARANNYA. 2019 Jul 31;14(2).

[7] Simanjuntak B, Limbong T. Using Google form for student worksheet as learning media. International Journal of Engineering \& Technology. 2018;7(3.4):321-4. 
[8] Yuwono MR, Udiyono U, Maarif DH, Sulistiana S. Students' Critical Thinking Profile To Solve The Problem Of Analytical Geometry Viewed From Gender. Al-Jabar: Jurnal Pendidikan Matematika. 2019 Jun 13;10(1):37-46.

[9] Bowen, GA. Analisis Dokumen sebagai Metode Penelitian Kualitatif. Jurnal penelitian kualitatif. 2009.

[10] Miftah M. Pemanfaatan media pembelajaran untuk peningkatan kualitas belajar siswa. Kwangsan. 2014;2(1): 1-11.

[11] Aryani F, Hiltrimartin C. Pengembangan LKS untuk metode penemuan terbimbing pada pembelajaran matematika kelas VIII di SMP Negeri 18 Palembang. Jurnal Pendidikan Matematika. 2011;5(2).

[12] Lutfianis JA, Wijaya AF, Purwanto P. Application Of Problem Based Learning Model Using Education For Sustainable Development Context In Improving Critical Thingking Ability For Junior High School Students At Heat Theory. Dinamika Jurnal Ilmiah Pendidikan Dasar. 2021 Mar 6;12(2):98-103.

[13] Dewi N, Hamdu G. LKS PEMBELAJARAN STEM BERDASARKAN KEMAMPUAN 4C DENGAN MEDIA LIGHTNING TAMIYA CAR. Jurnal Imiah Pendidikan dan Pembelajaran. 2020 Jul 2;4(2):369-78

[14] Lismayani I, Parno P, Mahanal S. The correlation of critical thinking skill and science problemsolving ability of junior high school students. Jurnal Pendidikan Sains. 2017;5(3):96-101.

[16] Yunita F. The use of Google Form application as media for students' assessment. InProceedings of International Conference on English Language Teaching (INACELT) 2019 Dec 25 (Vol. 3, No. 1, pp. 118127).

[17] Astuti Y, Setiawan B. Pengembangan lembar kerja siswa (LKS) berbasis pendekatan inkuiri terbimbing dalam pembelajaran kooperatif pada materi kalor. Jurnal Pendidikan IPA Indonesia. 2013;2(1).

[18] Ermi N. Penggunaan Media Lembar Kerja Siswa (LKS) Dalam Meningkatkan Hasil Belajar Sosiologi Siswa Kelas XI SMAN 15 Pekanbaru. Jurnal Pendidikan. 2017;8(1):37-45.

[19] Rizqiyana AF. STEM (SCIENCE, TECHNOLOGY, ENGINEERING, AND MATHEMATICS) APPROACHES USING THEMATIC LEARNING MEDIA TO DEVELOP CRITICAL THINKING. Dinamika Jurnal Ilmiah Pendidikan Dasar. 2021 Apr 1;13(1):20-5. 